\title{
A noninvasive imaging technique to evaluate therapeutic efficacy after injection of n-butyl-2- cyanoacrylate tissue adhesive into gastric varices: A case report
}

\author{
Bret J Spier MD ${ }^{1}$, Andrew J Taylor MD², Patrick R Pfau MD ${ }^{1}$, \\ Adnan Said MD MSPH ${ }^{1}$, Deepak V Gopal MD FRCPC FACP FASGE ${ }^{1}$
}

\begin{abstract}
BJ Spier, AJ Taylor, PR Pfau, A Said, DV Gopal. A noninvasive imaging technique to evaluate therapeutic efficacy after injection of n-butyl-2-cyanoacrylate tissue adhesive into gastric varices: A case report. Can J Gastroenterol 2009;23(6):412-414.

A novel use of multidetector computed tomographic intravenous (MDCT IV) portography in the evaluation of gastric varices treated with tissue adhesive is described. A 55-year-old man presented with upper gastrointestinal hemorrhage as a result of bleeding gastric varices. The patient was stabilized and the gastric varices were treated with n-butyl-2-cyanoacrylate (two injections, total $7.5 \mathrm{~mL}$ ). MDCT IV portography performed after injection revealed thrombosis of all but one of the submucosally based gastric varices. The endoscopist who performed repeat endoscopy three weeks later was then able to direct therapy at the remaining patent submucosally based gastric varix. This represents the first reported use of MDCT IV portography in the evaluation of treatment adequacy in a patient with gastric varices treated with n-butyl-2-cyanoacrylate.
\end{abstract}

Key Words: CT portography; Gastric varices; Surveillance; Tissue adhesive

$\mathrm{T}$ issue adhesives have been used for many years, and recent reports suggest benefit of their use in patients with portal hypertension and bleeding gastric varices (1-5). However, there is little evidence to suggest how patients should be evaluated for adequacy of therapy after treatment. Recently, we have successfully used multidetector computed tomographic intravenous (MDCT IV) portography to assess treatment adequacy. A case of gastric variceal injection using n-butyl-2-cyanoacrylate, with the successful use of MDCT IV portography to noninvasively evaluate the efficacy of endoscopic glue therapy, is reported.

\section{CASE PRESENTATION}

A 55-year-old man with previous alcohol abuse and no other significant medical history, experienced an episode of hematemesis. Initial upper endoscopy revealed only small esophageal varices and a large collection of gastric varices in the fundus, one being ulcerated and likely the bleeding source (Figure 1).

Before endoscopic treatment, the patient underwent MDCT IV portography to rule out a portal venous clot as well as to delineate the blood supply of the gastric varices (Figure 2 ). The
Une technique d'imagerie non effractive pour évaluer l'efficacité thérapeutique d'une injection d'adhésif tissulaire n-butyl-2cyanoacrylate dans des varices gastriques : Un rapport de cas

On décrit l'utilisation novatrice de la portographie tomodensitométrique intraveineuse à détecteurs multiples (TMIV-DM) pour évaluer des varices gastriques traitées par adhésif tissulaire. Un homme de 55 ans a consulté en raison d'une hémorragie gastro-intestinale haute causée par des varices gastriques hémorragiques. On a stabilisé le patient et traité les varices gastriques hémorragiques par injection d'adhésif tissulaire n-butyl-2cyanoacrylate (deux injections, total de 7,5 mL). La portographie TMIVDM effectuée après l'injection a révélé une thrombose de toutes les varices, sauf une varice gastrique sous-muqueuse. L'endoscopiste qui a repris l'endoscopie trois semaines plus tard a pu limiter le traitement à la varice gastrique sous-muqueuse restante et manifeste. C'est le premier usage déclaré de la portographie TMIV-DM pour évaluer la pertinence d'un traitement chez un patient ayant des varices gastriques traitées par n-butyl2-cyanoacrylate.

patient then underwent repeat upper endoscopy with injection of n-butyl-2-cyanoacrylate (two injections, total $7.5 \mathrm{~mL}$ ) via a 25-gauge Carr-Locke (US Endoscopy, USA) sclerotherapy needle into the ulcerated gastric varix. Follow-up MDCT IV portography revealed thrombosis of all but one of the submucosally based gastric varices (Figure 3 ). The patient had no evidence of rebleeding and was discharged on hospital day 4. Endoscopy performed one month later identified the remaining patent gastric varix noted on MDCT IV portography. The lesion was subsequently treated with $4 \mathrm{~mL}$ of n-butyl-2-cyanoacrylate.

\section{Injection Technique}

The n-butyl-2-cyanoacrylate (Henkel Loctite Corp, Ireland) was kept refrigerated, and was subsequently maintained on ice until the gastric varix was visualized. Eight $0.5 \mathrm{~mL}$ vials were drawn into a $10 \mathrm{~mL}$ syringe and injected via a 25-gauge CarrLocke sclerotherapy needle. A flexible sigmoidoscope (ES 3830; Pentax, USA) was used for the repeat esophagogastroduodenoscopy examination, to allow for a larger working channel and greater flexibility with retroflexion of the

${ }^{1}$ Section of Gastroenterology and Hepatology, Department of Medicine; ${ }^{2}$ Department of Radiology, University of Wisconsin School of Medicine and Public Health, Madison, Wisconsin, USA

Correspondence: Dr Bret J Spier, Department of Gastroenterology and Hepatology, University of Wisconsin Hospital and Clinics,

600 Highland Avenue, Madison, Wisconsin 53792, USA. Telephone 608-263-4033,fax 608-265-5677, e-mail bj.spier@hosp.wisc.edu

Received for publication May 9, 2008. Accepted June 4, 2008 

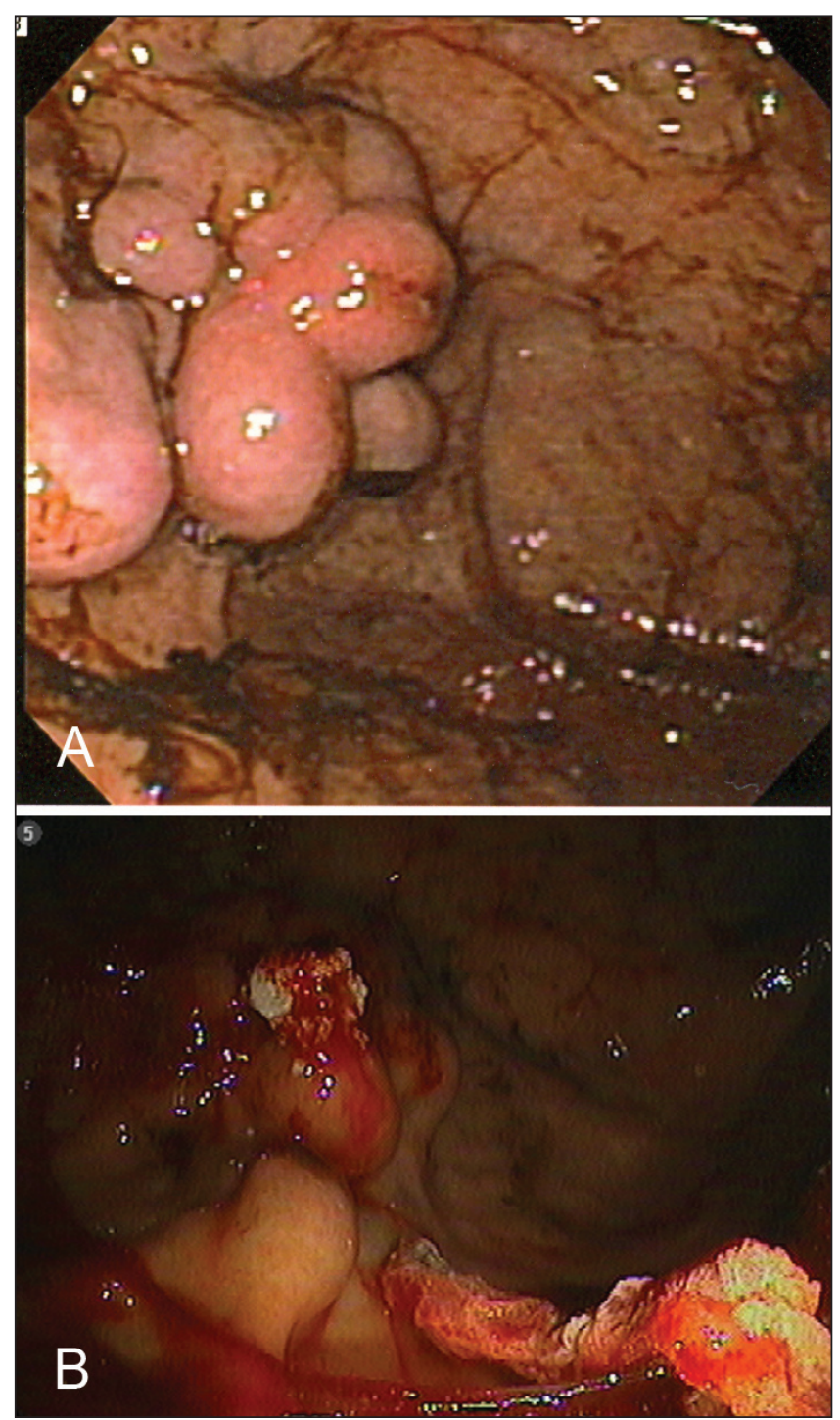

Figure 1) A Large collection of fundal gastric varices before treatment. One varix shows ulceration, suggesting the source of gastrointestinal hemorrhage. B Gastric varices after treatment with n-butyl-2-cyanoacrylate, with excellent hemostasis

gastroesophageal junction. The channel preparation technique using olive oil, was performed similar to that described by Caldwell et al (2). Under direct visualization, n-butyl-2-cyanoacrylate was then injected into the ulcerated gastric varix as previously described (2). Although the United States Food and Drug Administration approved its use as a tissue adhesive, the use of n-butyl-2-cyanoacrylate for the treatment of gastric varices is a well-described off-label use and, accordingly, appropriate informed patient consent was obtained for its use before the procedure.

\section{MDCT IV Portography}

MDCT IV portography was performed on a 64-channel scanner. Slice thicknesses of $5 \mathrm{~mm}$ taken every $3 \mathrm{~mm}$ were obtained. From this, $1.25 \mathrm{~mm}$ slices were reconstructed. These thin sections were used to reconstruct the portal venous system and left upper quadrant varices with maximum-intensity projection display. Intravenous injection of $150 \mathrm{~mL}$ of a $300 \mathrm{mg} / \mathrm{mL}$


Figure 2) Multidetector computed tomography (MDCT) scan of the varices network before treatment. A MDCT intravenous portography using three-dimensional reconstruction demonstrates the entire network of varices in the portal venous system including the gastric varices. B Sagittal two-dimensional reconstruction to visualize the varices at the gastric fundus (arrow)

low-osmolar iodinated contrast agent was performed, followed by a $50 \mathrm{~mL}$ saline flush, which was injected at $5 \mathrm{~mL} / \mathrm{s}$ with a $70 \mathrm{~s}$ delay. Reconstructions were performed on a three-dimensional workstation under the guidance of a radiologist (AJT) familiar with the case.

\section{DISCUSSION}

The treatment of gastric varices can be a challenge. Reducing portal pressure via a surgical or transvenous intrahepatic portosystemic shunt are options for the proper candidate. Injection of n-butyl-2-cyanoacrylate or other tissue adhesives for those who are not candidates for portosystemic shunting is proving to be a valuable alternative. However, there is no effective measure of treatment adequacy. The postprocedural demonstration of treatment should be safe, noninvasive, inexpensive, accurate and reproducible among institutions. 

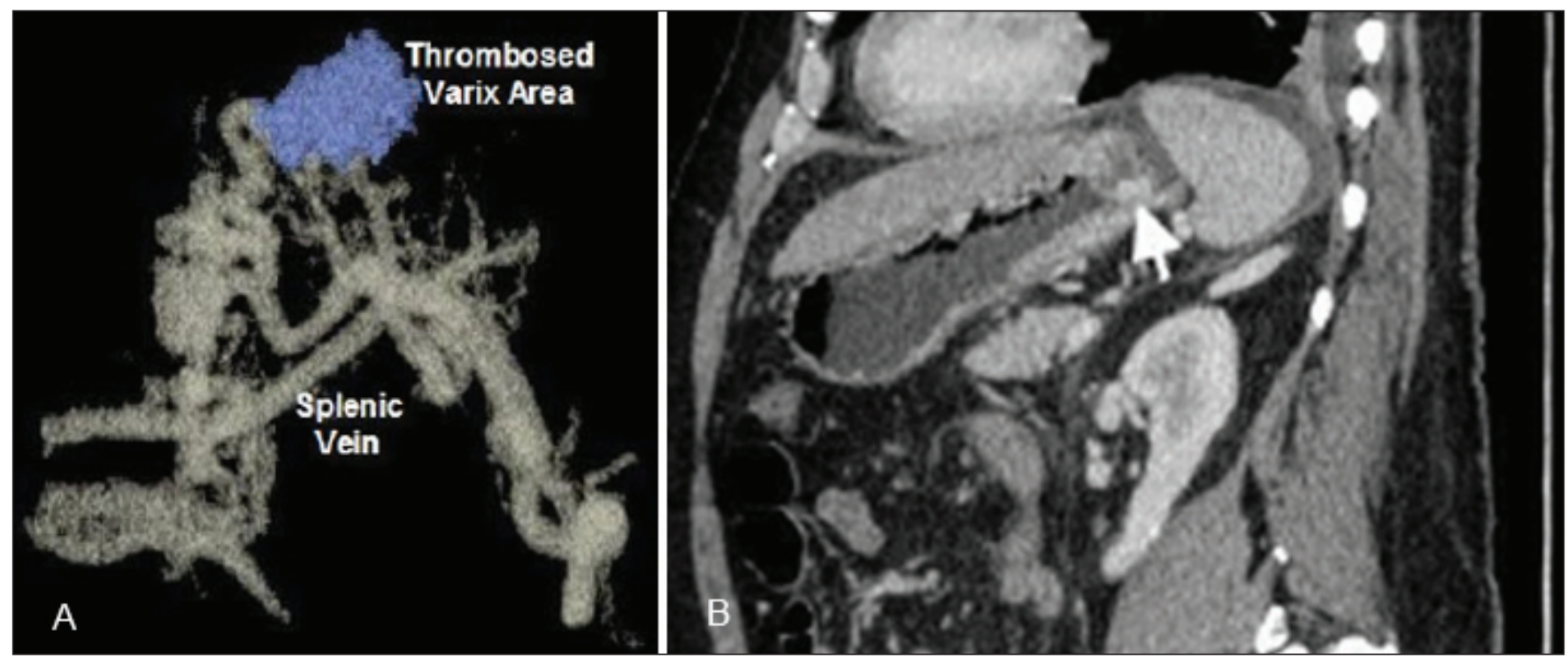

Figure 3) Multidetector computed tomography scan of the portal venous system following n-butyl-2-cyanoacrylate injection. A Threedimensional image of the remaining portal venous network with the area of variceal loss denoted by colour. B Sagittal two-dimensional reconstruction demonstrating that most of the fundal varices are absent. Still remaining, however, is a varix (arrow) just caudal to the treated side

The use of tissue adhesives creates a dilemma for determining adequate therapy. At repeat endoscopy, gastric varices treated with tissue adhesives appear as they were before treatment, but firm to probing. Endoscopic ultrasound has been shown effective in the diagnosis of varices before therapy $(6,7)$; however, after tissue adhesive injection, endoscopic ultrasound findings are of unclear significance (3).

We have successfully used MDCT IV portography as a noninvasive measure of treatment adequacy. Our post-treatment imaging revealed successful thrombosis of all submucosal gastric varices except for one collection, which was subsequently treated on follow-up endoscopy.

\section{CONCLUSION}

The present case demonstrates a novel use of MDCT IV portography for the evaluation of gastric varices that have been treated with tissue adhesive. This method will need further validation with larger studies, but appears to be a safe, noninvasive and reproducible approach to determine therapeutic efficacy.

\section{REFERENCES}

1. Mahadeva S, Bellamy MC, Kessel D, et al. Cost effectiveness of n-butyl-2-cyanoacrylate (Histoacryl) glue injections versus transjugular intrahepatic portosystemic shunt in the management of acute gastric variceal bleeding. Am J Gastroenterol 2003;98:2688-93.

2. Caldwell SH, Hespenheide EE, Greenwald BD, et al. Enbucrilate for gastric varices: Extended experience in 92 patients. Aliment Pharmacol Ther 2007;26:49-59.

3. Romero-Castro R, Pellicer-Bautista FJ, Jimenez-Saenz M, et al. EUS-guided injection of cyanoacrylate in perforating feeding veins in gastric varices: Results in 5 cases. Gastrointest Endosc 2007;66:402-7.

4. Sarin SK, Jain AK, Jain M, et al. A randomized controlled trial of cyanoacrylate versus alcohol injection in patients with isolated fundic varices. Am J Gastroenterol 2002;97:1010-5.

5. Lo GH, Liang HL, Chen WC, et al. A prospective, randomized controlled trial of transjugular intrahepatic portosystemic shunt versus cyanoacrylate injection in the prevention of gastric variceal rebleeding. Endoscopy 2007;39:679-85.

6. Lee YT, Chan FK, Ching JY, et al. Diagnosis of gastroesophageal varices and portal collateral venous abnormalities by endosonography in cirrhotic patients. Endoscopy 2002;34:391-8.

7. Faigel DO, Rosen HR, Sasaki A, et al. EUS in cirrhotic patients with and without prior variceal hemorrhage in comparison with noncirrhotic control subjects. Gastrointest Endosc 2000;52:455-62. 


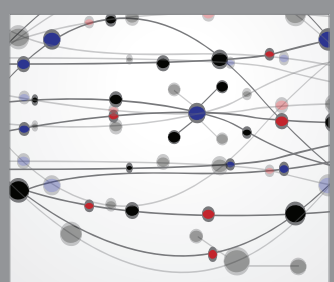

The Scientific World Journal
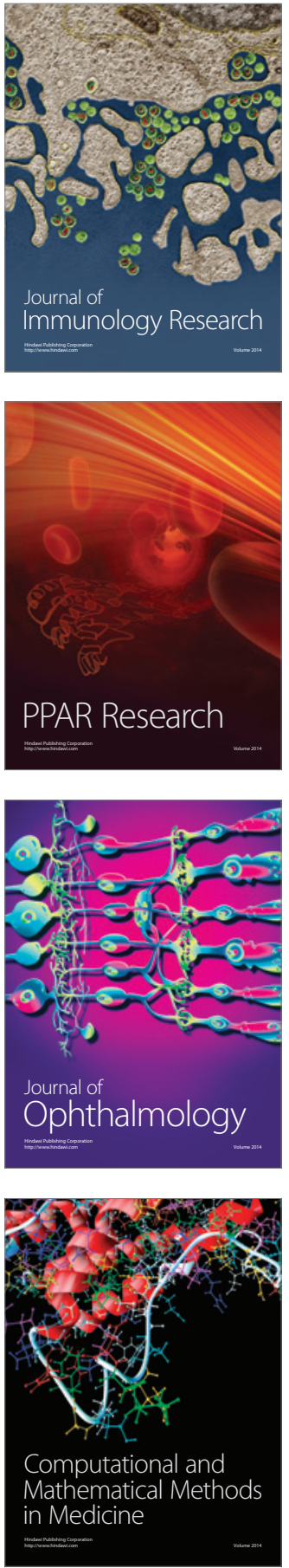

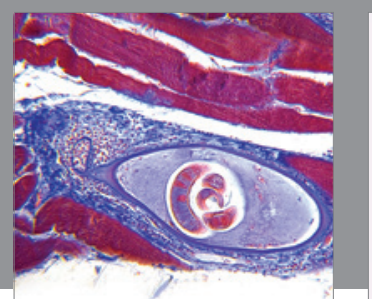

Gastroenterology Research and Practice

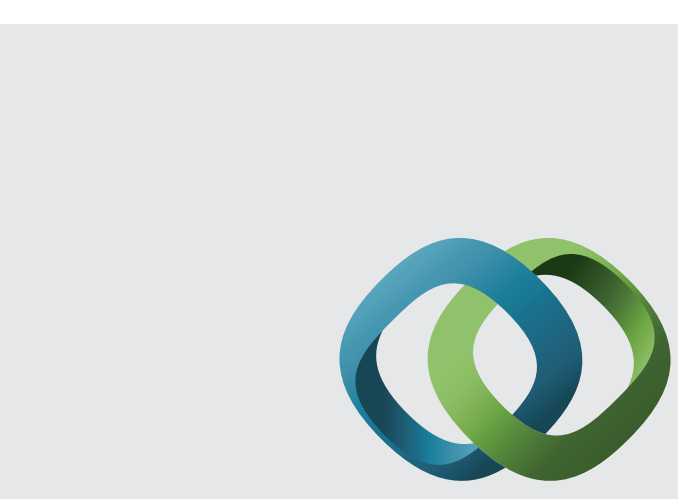

\section{Hindawi}

Submit your manuscripts at

http://www.hindawi.com
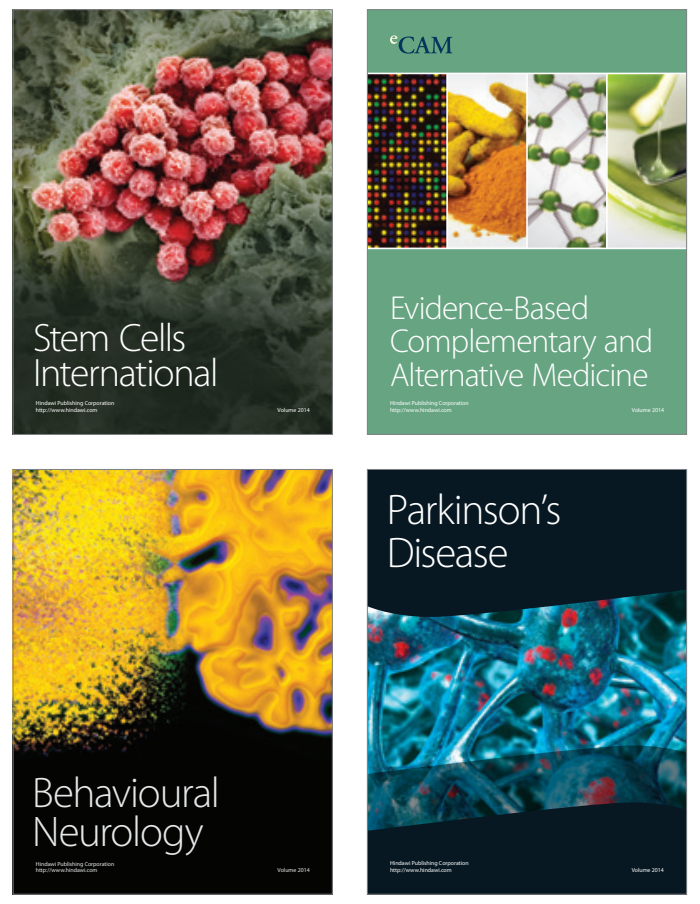
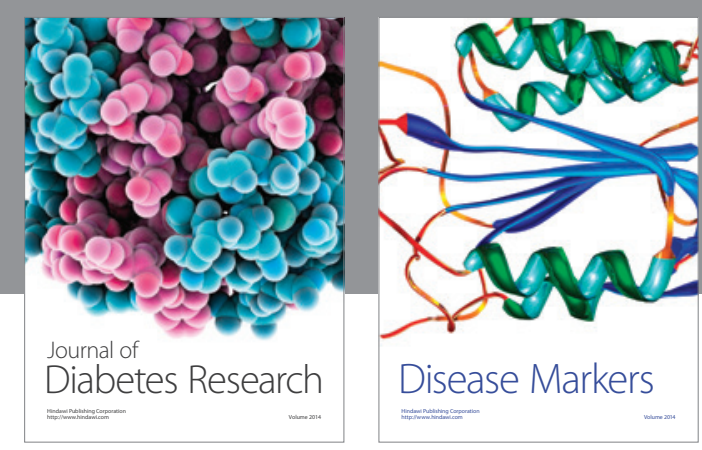

Disease Markers
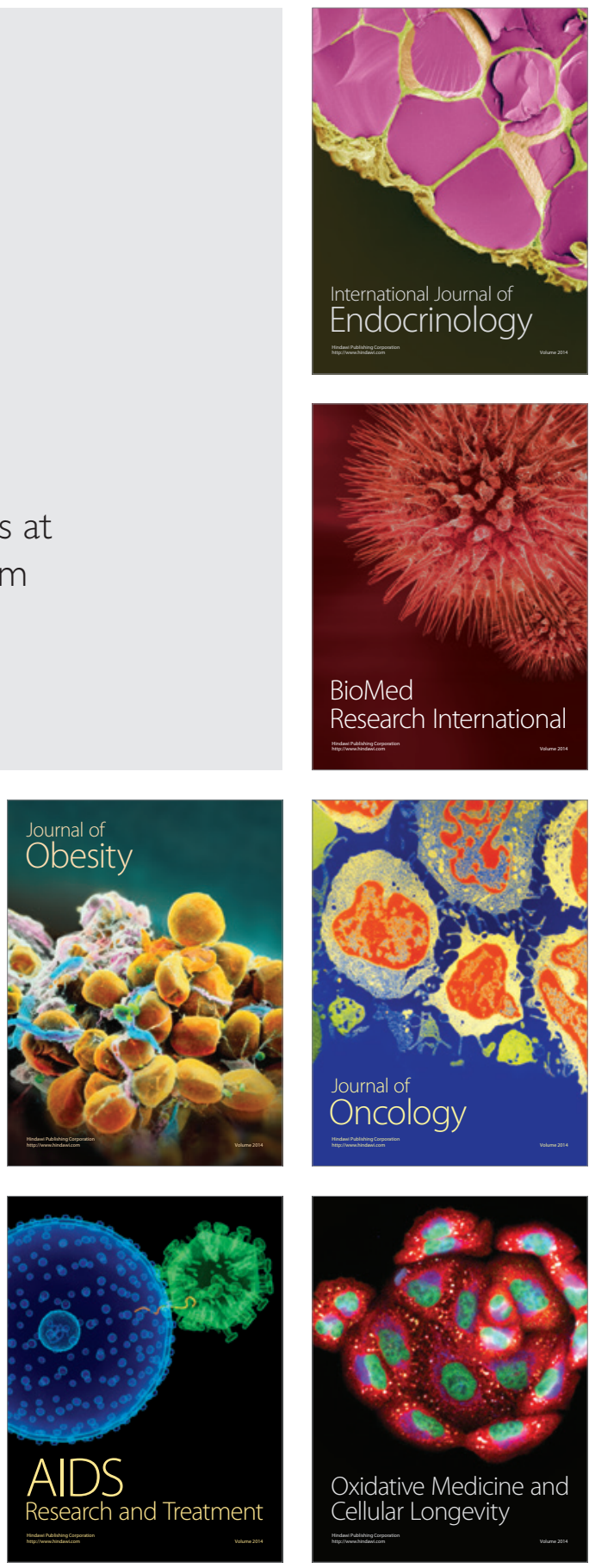